\title{
Uncovering emerging identity performances of Turkish foreign language teaching assistants
}

\author{
Nihan Bursalı a * (D), Hülya Mısır b (D) \\ ${ }^{a}$ Ufuk University, Faculty of Education, Foreign Language Education, Ankara 06830, Turkey \\ ${ }^{b}$ Cappadocia University, Faculty of Humanities, English Translation and Interpreting, Nevsehir 50420, Turkey
}

Received 15 December 2019 | Received in revised form 20 July 2020 | Accepted 14 October 2020

\begin{abstract}
APA Citation:
Bursalı, N., \& Misir, H. (2021). Uncovering emerging identity performances of Turkish foreign language teaching assistants. Eurasian Journal of Applied Linguistics, 7(1), 45-67.
\end{abstract}

Doi: http://dx.doi.org/10.32601/ejal.911161

\begin{abstract}
The aim of the study is to show emerging identity performances of Turkish Fulbright foreign teaching language assistants (FLTAs) in social and academic contexts during their sojourn experiences in the US. The grant program brings institutional roles of being a teacher and a learner and social duties of culture transmission in the host country. The dynamic triad of these roles yields negotiated identities manifested through reflections to the experiences of interaction, communication, and participation in the host community. In an attempt to reveal the interplay of these roles, 5 Turkish grantees were interviewed to elicit personal storylines. The narratives were analyzed adopting Davies and Harré's (1990) positioning theory rooted in discursive psychology relying on Bauman's (2013) postmodern conception of identity where identity is seen as fluid, multilayered, and negotiated. The participants' emerging identities formulated in the personal narratives are depicted through the negotiation of self-other positioning. The findings showed that affinity, racial, national, gender, cultural, second language, professional, and learner identities were revealed as emerging identity performances with an intersectional structure. This study provides a useful depiction of the FLTAs' sojourn experiences with a microanalytic eye and recommends covering different aspects with various focal points to better understand the educational and cultural aspects of such sojourn experiences.
\end{abstract}

(C) 2021 EJAL \& the Authors. Published by Eurasian Journal of Applied Linguistics (EJAL). This is an open-access article distributed under the terms and conditions of the Creative Commons Attribution license (CC BY-NC-ND) (http://creativecommons.org/licenses/by-nc-nd/4.0/).

Keywords: Foreign language teaching assistants; emerging identities; narration; positioning theory; sojourner

\section{Introduction}

The Fulbright Foreign Language Teaching Assistantship (FLTA) is an international exchange program for language teachers sponsored by the Bureau of Education and Cultural Affairs of the United States Department of State and administered by the Institute of International Education. FLTAs are recruited to teach their native language in the US every year, supervised by the head of the associated language program. The scholarship terms consist of teaching hours, taking graduate courses (a

\footnotetext{
* Corresponding author. Tel.: +90-312-586-7471

E-mail address: nihan.bursali@ufuk.edu.tr

http://dx.doi.org/10.32601/ejal.911161
} 
must course of American studies), administering cultural events, and promoting the language program. The FLTAs' practices during the program are situated in the interactions and participation in the community. What is known about the experiences of FLTAs in the US is that they are expected to maintain three roles: (i) teacher, (ii) learner, and (iii) cultural ambassador. The dynamic triad of these roles yields negotiated identities manifested through reflections to the experiences of interaction, communication, and participation in the host community. The context in which each FLTA carries out these roles differs depending on their host institutions in various areas of the United States. We conducted interviews with 5 FLTAs, who have been in 5 different states in the US, to elaborate on their experiences with their roles in the program. In the interviews, the storylines revealed how they problematized some sojourn experiences, which enabled the researchers to elicit the presentation of emerging identities in the construction of their stories.

Participants of this program are involved in social and academic discourse that bring about institutional duties, teacher and learner contexts, the social role of culture transmission in encounters in and out of campus, roles and duties in affinity groups, power distributions in academic and social discourse, and development of face-saving practices in these encounters during the sojourn experiences. Eliciting the details of these experiences requires particular attention to individuals' positioning of self and other(s) in narrating the lived experiences when residing abroad for a relatively short time. Narratives lead to a clearer understanding of lived experiences by individuals inasmuch as these stories shed light on how people position themselves and others in particular events and how they make sense of the events idiosyncratically or in a common way (Cortazzi, 2001).

Departing from the notion of emerging identities in narratives, this study aims to uncover the identity performances which emerge in the realization of the FLTA roles (social and academic) and are interpreted through positioning theory (Davies \& Harré, 1990), which comprises of the self and other entities in various discourses. To understand the international discourses better, narratives from a self perspective are analyzed regarding the positioning of both self and others depicted by the narrators.

\section{Literature Review}

The temporary residency has been increasing across the world, and the category of temporary residents has expanded to include diverse groups such as students, sojourners, travelers, seasonal workers, and expatriates (Pedersen et al., 2011). These individuals' experiences require interdisciplinary reading because small/large groups of people and their contexts in foreign environments show distinct qualities to attend. Concerning educational contexts, study abroad programs such as Erasmus exchange or other graduate scholarship programs are addressed in the literature for their prominent contexts and the imperatives of the conditions in such contexts. The subjects of sojourner experiences on which the imperatives have impinged have taken roles and duties that are context dependent. Therefore, it is essential to delineate these subjects' 
stories to understand how they define themselves and are shaping and shaped by the responsibilities in their socio-cultural contexts.

Psychological and socio-cultural challenges, especially sojourner adjustments to a foreign environment, result in building coping mechanisms in the discourse worlds where the subject performs certain identity performances. Identity appears to be an analytic tool to understand dynamic contexts and context-dependent behaviors within roles. Individuals do not explain who they are with the core identity, but with the blend of the instruments that context encapsulates, historically shaped experiences and beliefs we bring in the context, and formulated thoughts in the future. We can identify this continuum with Bauman's (2013) conceptualization of fluid identity, the most evident indicator of liquid modernity. He observed how people move among identity choices, and identities look temporary and are away from fixed and wrapped selfdefinitions. Thus, identity conceptualization goes beyond the static features of race, ethnicity, and gender and takes a fluid form.

Postmodernist conceptualization of identity defines it as fluid, multilayered, and negotiated. Howard (2000) discusses that the postmodernist conception of identity is strongly consistent with the recent research and empirical findings of social psychology in a way that a "single social position such as gender, race, ethnicity, class, sexuality, or age" leads to thinking of how these identities coincide (p. 381). Choosing one way of acting out a role does not prevent another from appearing at the lived moment. Multiple roles interact in discourse, for example, being both a student and teacher in a university, or a possible role switch is to be engendered.

When examining identity performances in discourse, it is also necessary to do an accurate examination of the other from a societal view since it is an integral part of the enacted behaviors. To reach a better understanding of discursive performances where self and other meet, scientific observation of social and political contexts in the host society is crucial. The social cues in these contexts are indexical and can be restated, reinstated, or reformulated in storylines or narratives. To create a cohesive story of the experienced, narrators accommodate themselves and others. They lend their voices to the characters in the stories and thus invoke the identities of social and cultural groups (Goffman, 1981); therefore, we must pay attention to the voices of the persons in which societies, communities, and native individuals are characterized in people's narratives. When we turn to institutional settings, Uzum (2017), in his data-driven analysis of language teacher narratives, illustrates how the content of teacher narratives included the self in the biographies and others such as colleagues, teaching supervisors/educators, and students in interactions during socialization into the teacher role.

Institutional and social roles are often normative, but positions people take are not static at all but negotiated and reformulated. Among many factors, how people take a position is affected by the roles they take and are assigned-these yield complex identity negotiation. Kayi-Aydar (2015a) investigated pre-service teachers' narrative positioning as they interact with their social context, arguing that teachers' self-other 
positioning is multifaceted and context-dependent. Her study illustrated that teachers developed conflicting positional identities in their stories. Examining the layers of narratives of the lived identities allowed them to reflect on teacher positioning within the educational system and culture. However, people's roles are not limited to their professional duties. Narratives often account for multiple roles rather than fixating on the normative duties of a single role. Multiple roles in a single interaction can yield to the creation of multiple identity performances in discourse. As Frable (1997) proposes, they should be taken as multiple identities of a whole person, and these identities are expected to be compatible with each other to make this whole person.

To uncover the identity composition, it is necessary to dwell on the self people display in the short- or long-term experiences of being in different cultures. The sojourn experiences performed in micro stages are influenced by the perceived social and institutional rules, culture, bilateral dialog, and membership dynamics, even if they last only a short time. These performances reveal social, cultural, national, racial, or language identity performances through the individuals' interpretation of their interactions. Numerous studies have examined these emerging identity performances in different settings (e.g., Giles \& Johnson, 1981; Hogg \& Abras,1988; Kayi-Aydar, 2015a, 2015b; Widdicombe \& Wooffitt, 1995). To illustrate, the study by Mutlu and Ortaçtepe (2016), exploring the foreign language teacher identity and identity shifts in the host community abroad through lived stories, confirms that people develop socially situated identities and reshape their ideal selves owing to their socialization practices in the host school culture. In their study, teachers appear to reflect on their second language identity in relation to their language teacher identity and (re)construct a selfimage negotiating their position in the macro system that produces a native-non-native dichotomy.

As implied earlier, positioning consists of not only the self but also the other. That is, it is always co-constructed where the interlocutor's position is assumed (van Langehove \& Harré, 1999). This can be explained by the relational quality of identity. We identify ourselves by being recognized by others. "Identity is, therefore, seen here as embedded in social relations and as dynamic, contextual and relational" (Andreouli, 2010, p.14.1). The other is not entirely a mystery to the self. Social knowledge and contextual clues help to decode the other. However, it does not necessarily mean the other is predictable at all times. Thus, identity positioning is negotiated in situ. This negotiation expresses the discursive nature of identity, and positioning theory views the other as an integral part of the negotiation process. For instance, Block and Corona's (2014) research illustrated the social class, racialized, ethnicized, and gendered positionings of Latino adolescents in Catalan society, highlighting the intersectionality of identity inscriptions. They did an analytical investigation of individuals and their environment in a diverse urban space and helped us understand how people negotiate identity performances when they are profiled based on the ascribed identities in the host society. Apart from the methodological contributions to identity studies, the narratives marked the influence of others' positioning on the subject's self-positioning. As Kayi-Aydar (2015a) put it, identity as multiple presentations of self is constructed and 
reconstructed within social contexts. Thus, one has to interpret the components of these identity performances (and the intersectionality) to make sense of the presentation of self in a specific context.

Besides, power dynamics are essential for the positioning theory as they form interactions and positioning processes through rights and duties, namely moral orders. These moral orders determine the actions in certain positions. For instance, the individuals' wordings or what they say and how they say it can be determined by these moral orders towards a specific interlocutor or specific context (Andreouli, 2010; Davies \& Harré, 1990). We interpret from a social angle that identity is discursive and has elements such as character, group membership, and positioning through others, and moral orders occurring in a particular position (Slocum-Bradley, 2010).

Power is also dynamic among affinity groups. Gee (2001) recognizes affinity groups as an integral part of identity composition, the rest of which comprises nature, institution, people's discourse, and dialog. He urges to define affinity groups as people involved in a group share and must be allegiant to and have access to a set of distinctive practices and ensure participation. It is this participation and sharing in affinity groups through which power works (p. 105). Such groups are determined by shared endeavors and similar traits that may or may not stem from culture. The workings of an affinity group vary, yet there is a common interest, little or more, for the subjects to form and carry out affinity identity. Mainstream literature often investigates affinity identity within communities of practice (CofP, Wenger, 1988) and highlighted membership practices for in/out-groups. Wenger proposed a framework of CofP, emphasizing the basis of membership, engagement, members' shared practices for their social and instrumental goals. In the process of negotiating membership in the community, individuals abide by identities on which CofPs have reached a mutual agreement. For sojourners, affinity group membership is an open space for constant negotiation and enacted the moment sojourners engage in communication in the host community.

Foreign Language Teaching Assistants in the US are still an understudied research topic despite its strong relevance to teacher identity, cross-cultural awareness, language and social dichotomies, and short-term migration phenomenon. Several studies have succeeded in shedding light on the lived experiences of the FLTAs in a variety of host communities. Uzum's (2012) ethnographic analysis of classroom discourse and Peker et al.'s (2020) study on the dynamic nature of language teacher identity are among the studies whose participants were Turkish FLTAs per se. Maloney (2018) focused on the impact of the FLTA program on the knowledge construction and the practices of technology for language teaching and learning of the program participants, analyzing various data sources to cover contextual factors at the macro, meso, and micro-levels. The studies in the literature majorly (and reasonably) concentrate on teacher identity negotiation/construction and socialization to American educational culture focusing heavily on pedagogical matters. However, studies whose subjects are foreign language teachers placed internationally do not elaborate on the nuances of social matters such as social workings of relationships, negotiation of self as a national/cultural persona, culture clash, or normative expectations from a foreigner 
in the host communities. It is significant to create awareness about such social matters without losing sight of institutional experiences since otherwise, international encounters may result in individuals' construction of racially, ethnically, or culturally insensitive ideologies and normative discourse. Therefore, our study, which also covers the classroom-oriented matters as it is the major trajectory with the program, aims to dwell on the nuances that emerged from self-other relations in both socio-cultural and institutional contexts.

\section{Theoretical Background}

Informed by the identity theories, this study employs an analytic framework that attempts to reveal the interplay of the roles and, thus, identity performances of FLTAs constructed in their narration of lived experiences. Therefore, the present study utilized positioning theory that is theoretically based on individuals' positioning of themselves in terms of self-other relations (Davies \& Harré, 1990; Harré, 2001; Harré \& Moghaddam, 2003; Harré \& Slocum, 2003; Harré \& van Langehove, 1991, 1999). The theory is discourse-oriented, and as Davies (2000) argues, "positioning is constantly in process; it only exists as process; it is revised and (re)presented through images, metaphors, storylines, and other features of language, such as pronoun grammar; it is spoken and re-spoken, each speaking existing in a palimpsest with the others" (p. 137). Deriving benefits from such a discourse analytic theory, the present study embarks on a linguistic and socio-cultural examination of sojourner narratives of their lived experiences.

Identity has an established relationship with narratives that goes back to Bruner (1990), who pioneered the use of narrative-based analysis as a theoretical approach in social sciences. De Fina (2015) argues that narrations have been seen as valuable tools to "express and negotiate both individual and collective identities" (p. 351). The critical point in De Fina's argument is that identities are negotiated and not merely static characteristics of a person or "manifestations of individual essence," and everyday narratives provide the space for the narrator to construct images of self and other, which revolves around identity performances (p. 351). Scholars who have majorly contributed to identity research, such as Giddens (1991) and Hall (1996), reject a core/central/unitary identity and define identity through a reflexive projection. The researchers of this study agree with the multiplicity of identity and thus follow an analytic approach to the storylines where the identity construction process is the focus in narratives. This means that what we analyze is not the cognitive processes of narrative constructions but also social aspects that entail this identity work.

How can we situate positioning theory in narratives? Individuals' lived experiences are embodied in their narratives, and narration becomes a means to evaluate/re-live the positions that the narrator (story owner) assigns to the self and other(s) during the experience and its narrative construction. These positions, just as the identities, are not static but discursive. Narrators take a stance to manage or manipulate these positions, basing their decisions on interpretations of social actors' roles and duties, 
including self in the narratives and on the social milieu (Breheny \& Stephens, 2015) where the experiences are shared with other people or objects. As in the lived version, one narrative triggers various identity performances because the front-stage discourse and back-stage discourse (Goffman, 1959) blend into a multilayered identity performance. Therefore, making sense of how the fluid and multilayered identities are manifested requires scrutiny into ongoing negotiation of social roles and self or other positioning in the narration.

In this study, we acknowledge that the academic and social discourses that comprise FLTAs' construction of the present narratives project the intertwined relations of past, present, and future discourses. The narratives of FLTAs in the present study enable us to elaborate on the contexts, identities, and interactions. The narration strategies that the narrator abides by allow us to elicit a topic, characters, encounters, spatial realities, namely, time and place, conflicts/resolutions, and a point of view. This study takes the narrators' voices to interpret their positioning in their interactions, such as affiliation or distancing with specific groups. It also includes their interlocutors' voice when they have had an explicit impact on how the narrators' position themselves and do identity work. Accordingly, the participants' narratives were analyzed to uncover the emerging identity performances with the help of positioning theory presented through the assigned roles in various discourses during the US assistantship program.

\section{Research Questions}

The present study conducts a qualitative analysis of the FLTAs' narratives of their sojourn experiences in the US to answer the questions below.

1. How is being a sojourner enacted in the positioning of self and other for the Foreign Language Teaching Assistants in performing their roles during their program?

2. What are the identity performances that emerged in the storylines of the Foreign Language Teaching Assistants in their social and academic interaction during their sojourn experience in the US.?

\section{Method}

\subsection{Setting and Participants}

For the present study, the participants were selected among Turkish Fulbright FLTA Grantees who are currently working as language instructors in different universities in Turkey. Therefore, criterion sampling was utilized (Miles \& Huberman, 1994). All these participants were employed as Turkish language instructors at the US universities. Also, the grantees were expected to attend audit and credit graduate courses at their host institution during the academic year of their program. All the participants resided in different states in different regions in the US The universities they worked/studied were among the best ranking in the country. The names of the grantees, the year of the program they were granted the scholarship, and their 
universities and states will be kept confidential. Since the program only grants a few people a year, such information would reveal the identities of the participants.

As it is a case study, a total of 5 participants were selected, which is a preferable number for a case study (Creswell, 2012). The participants all volunteered to be involved in the study, and semi-structured interviews were carried out individually on different days. Table 1 shows the demographic background information of the sample group.

Table 1. Demographic background information

\begin{tabular}{lllll}
\hline Pseudonyms & Age & Gender & Status of Courses & Professional role in the institution \\
\hline Emre & 33 & Male & All audit & Primary Teacher \\
Duru & 26 & Female & Three credit, one audit & Assistant \\
Ali & 27 & Male & All audit & Primary Teacher \\
Leyla & 31 & Female & All audit & Primary Teacher \\
Melis & 26 & Female & All audit & Assistant \\
\hline
\end{tabular}

As Table 1 shows, pseudonyms were generated to ensure the anonymity of the participants. The sample included three females and two males in the 26-33 age range. Almost all of the participants took the courses that the FLTA program required as audit except for Duru. Besides, the participants had two different professional roles in the host institution, working as either a primary teacher or assistant.

\subsection{Data Collection}

A qualitative case study research design was adopted, where we utilized interviews for data collection (Duff, 2012). 50-80-minute semi-structured interviews with each participant were carried out, which generated a 337 minute-recording. For the data collection procedure, semi-structured interviews are chosen since our data is based on the narration of the lived experiences abroad. We intend to cover every related detail that could answer our research questions. The interview questions were formulated by the authors of this study, one of whom was a former Turkish Fulbright FLTA grantee. Having a former FLTA in the research team greatly helped when constructing the interview questions due to her familiarity with the processes in the program. Then, these questions were consulted with a Turkish sociologist in a face-to-face meeting to determine potential pitfalls. Finally, we conducted a pilot interview with an FLTA different from the participants of this study to test the questions for their quality of comprehension and engagement and comprehension of questions. Several adjustments were made to make the interview process more engaging (see Appendix A \& B). All the interviews were conducted in the participants' native language, which is Turkish. The researcher, who was a Fulbright alumnus, conducted the interviews to reach a satisfactory level of rapport. Thus, we benefited from the listener's topical knowledge 
to elaborate on the questions and answers during the semi-structured interview. As De Fina and Georgakopoulou (2008) put it, the listener's role also plays an active role in shaping the narrations by broadening a narrow focus, triggering and challenging other perspectives.

\subsection{Data Analysis}

After conducting semi-structured interviews with each participant, the recorded interview data were transcribed orthographically. The researchers read the interview data several times, and initial coding was carried out by following positioning theory, namely self and other positionings (Table 2).

Table 2. Sample coding

\begin{tabular}{|c|c|c|c|}
\hline Data & Initial Coding & Second Coding & Final Category \\
\hline $\begin{array}{l}\text { 'Nobody invests in you because you } \\
\text { will leave.' } \\
\text { "I already knew the dynamic of being } \\
\text { an international student from my } \\
\text { friends here. I mean, the ones who } \\
\text { come here (Turkey) as an } \\
\text { international student. If you have a } \\
\text { limited time there (America), nobody } \\
\text { invests in you because you will leave. } \\
\text { I mean nobody thought that they } \\
\text { could have a link with me in the } \\
\text { future socially. Nobody initiates such } \\
\text { a link, but in fact, I was expecting } \\
\text { this." (Leyla, 31) }\end{array}$ & $\begin{array}{l}\text { I. pre-existing knowledge of } \\
\text { sojourn experience (self) } \\
\text { II. perception of the other(s)' } \\
\text { relationship investment } \\
\text { practice (other) } \\
\text { III. limited time abroad (self } \\
\text { and other) } \\
\text { IV. a temporary entity in } \\
\text { social integrity (self and other) } \\
\text { V. lack of social closeness at } \\
\text { the desired level (other) }\end{array}$ & $\begin{array}{l}=\text { Leyla accepts the } \\
\text { positioning formulated } \\
\text { by others, which is being } \\
\text { a sojourner and } \\
\text { naturalizes the lack of } \\
\text { social closeness of } \\
\text { other(s). } \\
=\text { positioning through } \\
\text { others in social contexts }\end{array}$ & $\begin{array}{l}==\text { affinity identity } / \\
\text { otherness }\end{array}$ \\
\hline
\end{tabular}

Before the final coding process, the researchers gathered to negotiate their coding results. Then, to reach a final coding template, the codes were categorized according to different identity performances, which turned to be affinity, racial, national, gender, cultural, second language identities, teacher, and learner. It should also be noted that both self and other positioning were present in identity performances. The whole coding and analysis procedures were carried out with the qualitative data analysis software, MAXQDA. When the data reached saturation, the extracts were selected to present the findings and translated into English.

\section{Findings and Discussions}

In this section, exemplary cases are presented through storylines from the interviews to depict the narrator's positions in their encounters in social and academic contexts during their sojourn experiences. Based on how the participants position themselves and other(s), we observe the emergence of identity performances in the course of narrating sojourn experiences, which are repeated in many stories the participants have told. The content of the narratives was elaborated regarding dynamic roles and challenges and communication in the host country, and the analytic framework applied 
demonstrated the emerging identity performances; (1) affinity identity, (2) racial identity, (3) national identity, (4) gender identity, (5) cultural identity, (6) second language identity, (7) professional (teacher) identity, and (8) learner identity. These performances seem to be categorized separately; however, they are far from being categorical and mostly interwoven in the lived identity as well as the narratives, as seen in the final extract. The example story parts aim to illustrate "how selves and identities are done in interactions in which narratives are made use of" (Bamberg, 2006, p. 146).

Centered in the sojourner experiences, affiliation or disaffiliation practices derive from the need for socialization and lead to generating affinity groups. What makes a group an affinity group is mainly participation and sharing (Gee, 2001). Friend-seeking, in this case, is a substantial practice in sojourn experience. This practice is echoed in the academic and social contexts of the FLTA program. Recognition of the workings of the social practice of friend-making by the sojourners has two ends. One stands out in the form of affiliation with international groups, whereas the other projects disaffiliation with the host communities. The two ends are reflected in selfidentification. In extract 1 , we observe an 'interest' that drives participation in sojourners' affinity groups. Ali underlines the dynamics of making friends in the host country where the workings of relationships vary based on the individuals' non/Americanness. Through the binary comparison, Ali shows an affiliation with the individuals who are also sojourners, whereas disaffiliation with 'Americans' with respect to a set of experiences of befriending non-Americans. He presents strong disaffiliation with 'Americans' in their approach to friendship, as Extract 1 illustrates below.

Extract 1 (affinity identity experiences) 'You can have that in common.'

"I felt like, and I am only comparing, I mean it's easier to make friends with people from other nations because they also need a friend. They also come from abroad like you; naturally, you have something in common. You can have that in common. So, it is a bit of a hassle for Americans to be friends with whom they are going to be friends. I mean, err how can I put it? Like Americans who are not very open, of course, this is the same with every nation. It is not easy to be friends. You can't be friends right away. They don't accept you; they won't do that for you." (Ali, 27)

Emre's marginalized position; however, is more other-originated than self-originated. Extract 2 shows that he experienced similar dis/affiliation practices as Ali did. He positions himself as an outsider in the class. The asserted reasons that cause him to feel isolated are the impositions of both physical means like class size and social behaviors practiced by others toward the 'foreign.' He clearly desired to be engaged in the course, expecting an inclusive manner. His expectation is that the teacher would create space for a cross-cultural comparison or interaction and make him/them a recognized member/learner of the group. Teachers' creation of discriminatory professional environments prevents individuals from participating in social action and 
thus generates marginalized groups. This example clearly grounds that otherness can be other-originated by means of the social behaviors of others.

Extract 2 (affinity identity- otherness) 'We were obviously excluded in that class.'

"Did I participate in the courses? No. Because the course was about their culture. I mean, they were talking about something that I had never heard of. There was not a case that I can compare such as our music is like this, but your music is like that kind of stuff $[\ldots]$

We were auditing American Music. Well, because we were just auditing. This is very interesting. I don't know. Probably because of the class size. We were seated on a bench with my Filipino friend (another FLTA). We were hanging there on a separate corner. Imagine two round tables. Students are sitting around them. And we were sitting on that corner. I mean, in a place independent of that class. I think we were obviously excluded in that class. [...] I didn't feel very good. I was already-I mean, I have seen so many racist attitudes and so on as I was in Midwest. So, I thought it was not something unexpected. I thought, 'so what? Don't say anything, Emre.' I mean, it is okay like this. Our professor had such an attitude. I feel like... I mean, we were sitting at that corner because of it. How could I participate in that course when I was alienated like this?" (Emre, 33)

Linguistically marked in his narration, Emre uses inclusive 'we' to indicate his assignment of positions to the class members. A 'we' functions bi-directionally; it simultaneously includes some and excludes other(s), creating an us and them dichotomy. It is evidenced that Emre develops a dismissive position toward discriminatory behaviors and his alienation that he interprets as racist attitudes toward non-Americans. The discriminatory practices in a multicultural class can cause internalization and naturalization of such behaviors, as in Emre's case, resulting in the production and dissemination of racist discourse. Such socially alienated positions can turn multicultural spaces into uncomfortable zones because social alienation is a problematic state that causes social relationships to corrupt and ends in conflict situations. This particular finding is a prominent issue of inclusion/exclusion in classroom discourse where international education research focused on the voice of the 'outsider' (Sato \& Hodge, 2013; Spurling, 2006).

Racial identities are slippery concepts, as much as identities in general, and can be traced with individuals' self-identification in different times and spaces. However, these identifications are not sole products of the individuals; instead, they are bound to the existing recognized social categories (Rosenberg, 1979). Extract 3 depicts Duru's racial identity as she encounters a person who has an opinion about Duru's origin and expects confirmation. Despite Duru's claims of not having thought about the origin matter before, her response to being of Asian origin is formulated negatively. She elaborates on her confusion with the identification of her origin during the whole sojourn experience. Her bewilderment rises as her interlocutor's initial question turns to be a statement that desperately seeks validation. This phenomenon evolves into a realization of her uncertainty concerning racial self-identification. The questioning of 
racial 'self' is indeed initiated by the interlocutor, which reveals Duru's dilemma of racial self-identification. Later, she seems to settle on the idea that racial identification derives not from information systems such as geography or culture but is contained within oneself. Soon after, we observe an acknowledgment of the opposition of others for her racial identification with European origin, which shows the boundary of the recognized social category, making her unable to choose European origin. Then, she becomes aware that her racial identity is formulated over an Islam-based Middle East geography along with Asian geography, yet her opposition pays regard to physical appearance through which she asserts 'almost black' or 'black' cannot belong to the alleged geographies.

Extract 3 (racial identity) 'What am I?'

"A guy came to me asking 'you are Asian, aren't you?' There wasn't a moment like it in my life. I had never thought about it. I said, 'no, I am not.' This thing had gone on during my whole FLTA thing. I remember thinking about the problem of which box (in official documents) I am going to tick among these. Is it culture, is it geography? I don't know what you confirm to [...] the guy was shocked too. He said, 'no, you are Asian.' I said, 'no, I am not.' He keeps arguing with me over my Asianness. Yes, you are. No, I am not. For a moment, I was like, what am I?

[...] He made me question it. What am I? And eventually, I thought and decided, 'I am what I feel I am' because, I mean, I clearly want to say I am European, but we are not; people go against me. Because they say 'no you aren't (European), you are Islambased, so you belong to the Middle East. You are a Middle Easterner.' [...] I told him, look, do I look like Asian, look at my eyes, do I even resemble? I am almost black. I look more black." (Duru, 26)

We argue that the confusion with both interlocutors in Duru's story regarding the racial categorization of a Turkish person stems from insufficient knowledge of whose information system to confine to for racial categorizations. However, such attributions may not always be recognized as the rejection of Duru's European identity by the others who have had the right to act based on their long-running racial categorization of the Asian or European.

Wodak, De Cillia, Reisigl, and Liebhart (2009) propose that national identity is discursively constructed in talk, and the perception of national identity is broader than a 'political' subject and includes cultural elements. It is rather about collectively shared emotional dispositions, attitudes, and behavioral conventions that people of the same nation have "internalised through socialisation" (p. 4). Everyday discourses reveal that exclusionary practices in the name of nationalism can occur almost arbitrarily and manifest, in Melis' words in Extract 4, 'prejudgment,' 'accusation,' and 'ignorance.' Melis narrates her interpretation of the questions addressed to her about riding camels in Turkey, referring to politics and asserted distinctions among the national communities (everyday matters; transportation, clothing). On the one hand, since national identification is rooted in what Bauman (2013) defines collective identities, members of a national community formulate strategies to protect this 
'fragile' national self from any kinds of attacks, which simultaneously constructs distinctions between the members of a nation and other nations (Wodak et al., 2009). Melis' observed performance in advocating the national practices in Turkish politics despite her impartial stand in her country's politics emerges as a defense mechanism toward the encounters' misleading views of the realities of foreign lands (Turkey in this case).

Extract 4 (national identity) 'Are you really riding camels in Turkey?'

“Once, I came across the question, 'Are you really riding camels in Turkey?' I think it was about being in Texas. I mean, maybe the people living in Texas are not really into the world. For example, when it is asked where Turkey is, they cannot locate it on the Middle East map, or they asked me, 'you are wearing these kinds of clothes, but do you also wear these clothes when you are in Turkey?.' I heard so many things like this. They were extremely prejudiced about our politics. I do not also support our politics totally, but I sometimes felt that they were treating me in an accusing way. Then, I said something about their politics like yours is not as pure as the driven snow because I do not want to be outdone, so I sometimes get mad." (Melis, 26)

On the other hand, information-seeking questions led by ignorance can easily cause a threat to people's positive face, putting individual relationships at risk. It is seen that Melis positions others as prejudiced and takes a defensive position. It damages one's public self-presentation as a member of a national community. Evidenced in her use of 'our politics' and 'their politics', she develops a distancing position as she felt being accused of the current workings of national politics in Turkey. This drives her closer to defend the alleged mentality of nations. She takes an emotional stance rather than an analytic one and spotlights the alleged political wrongdoings of the other party's nation. Emotional reactions function as face-saving/losing acts that affect the individuals' position, especially in international encounters. This narrative shows that the emergence of national identity in difference-sensitive discourses puts sojourners in a vulnerable position and creates a deference zone. It marks the 'sanctity' of national identity. Following Anderson (1983) and later Wodak et al. (2009), we see that people's mental construct of a nation politicizes them, and the influence of sociopolitical forces (Howard, 2000) appears to bring into the national identity that is exercised with or against certain communities.

The FLTA program also assigns the grantees the role of cultural ambassador through which traditional practices and highlights of socio-cultural elements are displayed. Extract 5 is a clear indication of how orientalism is shaped in its very active form through gender. The dance show appears to be a cultural product that creates space for reproducing the 'exotic' East through a prevalent image of women. The extract exemplifies Duru's disturbance and worries as one of the two women at the department that the organizers asked her to perform a dance show in a cultural event. This is problematized in several ways. The exotic East is embodied in dance. Duru appears to resist the prevalent ideology around women's bodies and dance in the Orient. On the other hand, the demand for a dance performance controls and dominates the so-called 
space open for cultural exchange. For women, this space is reserved for a stereotyped image of the culture of the Other. There seems to be no neutral space for the real woman/ real Orient to exercise agency (Lewis, 2003). This example reveals how the produced national and cultural positionalities genders the Orientalist cultural product. The dance show is a discursive apparatus representing the gendered discourse, and Duru challenges the stereotypes as her assignment.

Extract 5 (gender identity) 'We are two girls, so they come to us.'

"Our institution expected something, like a dance, especially folkloric dance showcase, from girls in particular. Perform a dance! Now, there is me at the department, an Uzbek that is male er Kirghiz that is male, and there are Mogul and Kazak that are male. We are two girls (with a Kazak girl), so they come to us. Do you want to dance at this event? [...] I wouldn't go out and dance, I would never, I would never. My friend is a more traditional girl and felt the pressure to do it, so she had to accept it just to shut their mouth. "(Duru, 26)

She is aware that this threatens her feminine agency and produces positions to which she refuses to confine. The risk is to reproduce the oriental woman and body as a fantasized image by the Western organizers to entertain the modern Western gaze. We observe Duru's uncompromising response to this gendered discourse. Her strong reaction is grounded in the orientalist gendered representation of women and the body. On the other hand, Duru's narration mentions the power exercised on her friend, where she gives in to the institutional duties, unlike Duru standing for her right as a woman to choose not to do a folkloric dance for an event. The salient statement here is that Duru relates the act of settling for a dispreferred practice to being traditional, which is a quality that she diverges herself from via presenting a nontraditional gender identity, where she manifests opposition to conforming to powerlessness. Refusing to take on the gendered identity she is presumed to perform by means of dancing, she assumes a 'nonconservative' role for herself as opposed to her friend, who is conforming to the conventional female perception to shut their mouth. It appears that traditional reading of gender by the society assumes such contractual meanings for being gender (Butler, 1999; West \& Zimmerman, 1987) and conforming to generic categories.

The concept of cultural identity is possibly hard to define, yet in intercultural communication studies, it is commonly regarded as "a localized national culture" (Dervin, 2012, p. 182). In this study, we also offer a prominent finding in which Duru's cultural identity is presented in the university context. We observe a conflict that stems from the intercultural differences where she is troubled with personal distance in the classroom setting. In Extract 6, Duru's narration shows that her construction of a caring teacher is resisted due to the students' interpretation of her socially deviant (for them) behaviors. The emphasis on the unconsciousness of the action performed marks a socially transferred act from her native culture, which is also explained by previous scholars such as Duff and Uchida (1997). Their work indicates that teachers' cultural practices are deeply rooted in their cultural background, previous teaching and learning experiences. 
Extract 6 (cultural identity) 'Keep your distance when you are talking with them.'

"This issue applies to America. I got warnings from my supervisor (a Turkish person) once or twice about personal space. She knew I didn't mean bad when I was sitting next to them (the students) very close when they talk. For example, they would sit in a chair, and I would crouch next to the chair and say 'yes I am listening' with my eyes fixed on the person, very engaged, to show I am interested. I didn't do it with malicious intentions, or it is not something I did consciously, but I remember my supervisor telling me 'they don't like it, and I also got such warnings from people back in time. I don't see any problem with you being sincere but really, keep your distance when you are talking with them.' [...] It is okay in Turkey, but it isn't, unfortunately, in America. I mean, it is like 'you are invading my space, listen to me, but from a mile away.' I couldn't help it, and I still found myself leaning to the desk, suddenly realizing it, and withdrawing." (Duru, 26)

Her behaviors are also remarked by the Turkish supervisor, the primary teacher of the Turkish class, that a negative attitude toward the violation of personal space in an American context had occurred before. The supervisor's previous experience with the matter allows her to empathize with Duru, which prompts a matter of shared social knowledge between them. Also, Duru's good intentions "being sincere" is legitimized in formal discourse by the supervisor, yet the performed action is not empowered. Duru's positioning is based on her claims of the appropriated action for the Turkish case and her desire to sustain it in the host culture. She refers to American students' demands of keeping distance, which clashes with her cultural identity regarding personal distance along with her caring teacher identity established in Turkish education discourse. Therefore, her endeavor to adapt partially fails. However, these practices can be reshaped through constant interaction with the students in the host culture. Duru's case supports this argument that her cultural identity began to transform through her professional practices guided by the feedback she receives from other(s). However, the stance enforced to her, which aligns her cultural posture inside the classroom may lead to monolithic cultural dominance and reduce the transcultural qualities of the classroom. Thus, opportunities for intercultural development may be diminished (Ryan, 2013).

During people's engagement in conversation with speakers of other languages, phonological features can indicate socially constructed categories (Huang, 2014). As Fuertes, Gottdiener, Martin, Gilbert, and Giles (2012) state, the accent is an immediate marker that determines the listener's judgment of the speaker's social group and the accent variety with which the group is affiliated. Non-native speakers (NNS) of English are easily cast as the Other when their accent diverges from the so-called 'standard' accent or the 'right' accent. A mismatch between the perceived 'right accent' and the NNS accent grounds the second language identity (Block, 2009). Emre's narration of his experiences with native and non-native speakers of English reveals the accentrelated discourse in which he stands to guard his language identity as an invested English speaker and professional. Having different experiences with the 'native' and 'non-native' interlocutors, Emre gradually builds an argument in his narration that 
positions 'native' English speakers as a source of anxiety. The narrative mode shows that people noticing his accent manifest a behavioral pattern that threatens his language identity. Such behavioral patterns may eventuate in accent prejudice or accentism toward L2 English accent varieties. It causes anxiety and casts doubt on an invested language learner/teacher's second language identity. Thus, othering discourse can grow stronger when one party in a conversation needs to build a defense (people make mistakes, and natives should have inferential skills in Extract 7) to protect face and self-esteem as a language speaker. It is damaging to stigmatize a language learner and teacher for his non-standard accent. If people's social interpretation of accents is based on negative experiences in the host community (especially in-service teachers of foreign languages), it may lead to a loss of prestige with non-native accents and result in the formulation and dissemination of normative language ideologies concerning native speakerism. More specifically, the reflection of such ideologies in the educational contexts can cause legitimization and naturalization of the notion of default or idealized accent rather than deconstructing the aspects of native speakerism and guiding the language learning processes with the intention of intelligibility. A value-oriented approach raises fundamental questions about the understanding of accents and accented speech in the global sense.

Extract 7 (Second Language Identity) "While I was talking to Americans, they made me feel nervous."

"[...] I did not have so much difficulty while I was communicating with non-native people; however, while communicating with Americans, I had a very difficult time. Because I do not know what is happening, but maybe it is because sometimes people may mispronounce little things. But you can interpret what has been said, can't you! [...] you may infer it from the context. I realized that they do not have that kind of skill. Because for example, while I was talking to Americans, they made me feel nervous. Because while I was trying to say something, they do this (squinting) as if they were trying to understand what I am saying. I form sentences that have the correct word order. I might not talk like you (referring to native speakers), I might not use slang or any other thing like you, I might talk as if I was uttering bookish sentences, but I think I can express myself. But Americans made me feel nervous. Especially when my accent took their attention, this was mostly their second sentence, "Oh! You have an accent." [...] I felt angry when this happened during communication." (Emre, 33)

The severance between the native speaker (NS) and non-native speaker (NNS) is vital as they both present symbolic meanings for an individual while making meanings about power and analyzing power (Huang, 2014). This power issue may be attributed to the global idea of NS and NNS in which NSs are considered as "privileged" while NNSs are considered as "subordinated" (Huang, 2018). In Extract 8, Duru's positioning in terms of power may be linked to this issue as she assigned a certain level of power to NSs teachers, and she experienced a shift in terms of nativeness. Her narration illustrates that Duru shares her power as a native teacher with other tutors, which affects her positioning in terms of duties. However, she desires to have all the power as 
she has never experienced nativeness in her professional life. When she gets the native teacher position, she does not want to share it. Namely, her responsibility reduces, and all these contextualized negotiations of positioning create this power struggle through rights and duties.

Extract 8 (Teacher identity) 'I wanted to be the one.'

"As there were the students' own tutors, this situation relieved me of my responsibilities. But, in another way, I wanted to be the one. I mean, I wanted to be the only native as I became a native (teacher) for once in my life. I wanted to be precious, but I was not that precious. Yes, this situation took responsibility from me, but there are others like me. I was not cherished or precious. 'Oh God, you are our only Turk, and that is you, we depend on you, we cannot let you go' kind of feelings. I just could not get that from the students. We loved each other, but there was a tutor, another student had a Turkish roommate, and so on. There were Turks everywhere." (Duru, 26)

Even though the FLTA program offers three different main roles -teacher, learner, cultural ambassador- for the participants, it is observable that intersectionality plays an essential role in terms of identity negotiation. Extract 9 offers a clear exemplar context in which both learner and teacher identities are observable simultaneously and clarifies the intersectional character of these two identities. Emre mentions taking Spanish lessons, which provides a context in which, besides possible other roles, the learner role is expected to emerge. However, his focus during these classes has been rather on what he would learn from his teachers, not for the course content but the teachers' way of using a specific tool to enhance his Turkish language teaching class, which would possibly empower his professional practices. Thus, he fulfills both learner and teacher identities in the course of a language class by positioning himself as an observer teacher who examines his colleagues' language classes in addition to being a Spanish language learner. Thus, his case indicates how he manifests multiple identities (Howard, 2000), or it can refer to intersectionality (Block \& Corona, 2014), as a learner and teacher in an educational context. That both identities intersect indicates that teacher identity is somehow inseparable from FLTAs' roles even if they are not in the teacher's position in a specific context. We argue that individuals may bring their professional identity even though they have been assigned different roles in a particular context.

Extract 9 (Intersection of learner and teacher identities) 'how to make language teaching better.'

"I guess the best part of my FLTA experience was participating in Spanish lessons. I learned a lot from the Spanish language teachers, not in terms of the Spanish language but about how to make language teaching better. Because they constantly teach the lessons with PowerPoint presentations, but they made use of such effects and activities that the lessons became so interactive. And also, indeed, I learned a lot from them." (Emre, 33) 


\section{Conclusions}

Resting upon positioning theory in storylines, this study contributes to the explorations of emerging identities of Turkish FLTAs during their sojourn experience. This study carried out a microanalytic lens to the social and academic discourses of FLTAs as sojourners through delving into personal stories of being a teacher, learner, and a social and cultural being. Presentation of sojourner challenges in this paper introduces the adaptation and otherizing issues going beyond the professional discourse of teacher-learner interaction and aggregates the social and cultural interactions as an inseparable discourse to ensure integrity for understanding the dynamics of international education. That is, the positioning taken as teachers or learners by the participants cannot be interpreted alone to explain otherness and adaptation problems occurring in social life as there are always other encounters in social interaction. What is visible in the course of social interaction throughout the sojourn program in this paper is intersectionality in identity performances. Even though the FLTA program assigns three main roles to the grantees, almost all of the extracts show the traces of different identities emerging simultaneously. There is always an intricate relationship between these positions as individuals cannot refrain from their gender, cultural, national, or professional identities in social interaction; instead, they are all contained in oneself. In social interaction, individuals may show different identity performances when they are assigned other positioning.

Studies examining the FLTA or other long/short-term academic programs generally aim to observe classroom discourse or context. Similarly, the part of our findings focusing on learning and teaching of languages benefits the language teachers engaged in multicultural classrooms as much as international education research. One prominent conclusion to underline is that teacher attitudes toward foreign students may unwittingly discourage them from participating in learning as well as establishing membership among peer groups that could enrich the experiences for both the 'host' and the 'guest.' On the other hand, the episodes of lived experiences in narratives, as seen in the example extracts, are related to other global and critical issues in both educational and cultural settings. Studies employing the ethnomethodological approach have prevalent success in explaining social interaction and discourse, and the method would be a resource for future studies investigating sojourners' engagement with educational and social practices.

Our study demonstrates that the FLTA journey is an academic migration, and like any individuals with immigration experience, the FLTAs suffer from problematic discourses, including racism, nationalism, linguicism, or gender. We acknowledge that every episode in which emerging identity performances are presented requires critical analysis, and the data of this study can only provide a glimpse into potentially problematic discourses evolved around being a sojourner engaging in the educational and social culture of the host community. Overt or covert othering is nested in the individuals' and communities' perception of the Other, reflecting on interpersonal relationships and more global phenomena. For this reason, as legitimate peripheral 
participants of academic and social circles, the academic migrants, like the FLTAs, must be critical-minded and challenge the mainstream ideologies and stereotypes about their culture in the host communities. One way to achieve it can be creating a discourse where differences are acknowledged and appreciated yet not overemphasized. The solution requires a mutual effort that is beyond reductionist solutions, such as cursory orientation programs targeting a complete alignment of the newcomers to the existing education culture. International education authorities, supervisors, and students who are enrolled in host universities have responsibilities as much as visiting groups of individuals to be aware of and informed by the merits of cultural differences and invite possible interculturality opportunities in the communities.

\section{Acknowledgments}

We would like to thank the participants who share their experiences with us. We are also grateful for the reviewers' insightful comments.

\section{The Research and Publication Ethics Statement}

No ethical considerations were violated in this study.

\section{The Conflict of Interest Statement}

In line with the statement of Committee on Publication Ethics (COPE), we hereby declare that we had no conflicting interests regarding any parties of this study.

\section{References}

Anderson, B. (1983). Imagined communities: Reflections on the origin and spread of nationalism. New York, NY: Verso Books.

Andreouli, E. (2010). Identity, positioning and self-other relations. Papers on Social Representations, 19(1), 14.1-14.13.

Bamberg, M. (2006). Stories: Big or small: Why do we care?. Narrative Inquiry, 16, 139-147.

Bauman, Z. (2013). Identity: Conversations with Benedetto Vecchi. New Jersey, NJ: John Wiley \& Sons.

Block, D. (2009). Second language identities. London, UK: Continuum.

Block, D., \& Corona, V. (2014) Exploring class-based intersectionality. Language, Culture and Curriculum, 27:(1), 27-42, doi: 10.1080/07908318.2014.894053

Breheny, M., \& Stephens, C. (2015). Approaches to narrative analysis: Using persona dialogical and social stories to promote peace. Peace Psychology Book Series Methodologies in Peace Psychology, 26, 275-291.

Bruner, J. S. (1990). Acts of meaning. Cambridge, UK: Harvard University Press.

Butler, J. (2011). Gender trouble: Feminism and the subversion of identity. New York, NY: Routledge.

Cortazzi, M. (2001). Narrative analysis in ethnography. In P. Atkinson, A. Coffey, S. Delamont, J. Lofland, \& L. Lofland (Eds.), Handbook of ethnography. Thousand Oaks: Sage.

Creswell, J. W. (2012). Qualitative inquiry and research design: Choosing among five approaches. Thousand Oaks, CA: SAGE Publications.

Davies, B. (2000). A body of writing: 1990-1999. Walnut Creek, CA: Altamira Press. 
Davies, B., \& Harré, R. (1990). Positioning: The discursive production of selves. Journal for the Theory of Social Behaviour, 20(1), 43-63.

De Fina A (2015) Narrative and identity. In A. De Fina , \& A. Georgakopoulou (Eds.), Handbook of narrative analysis (pp. 369-387). Malden, MA: Wiley-Blackwell.

De Fina, A., \& Georgakopoulou, A. (2008). Analysing narratives as practices. Qualitative Research, 8(3), 379-387.

Dervin, F. (2012). Cultural identity, representation and othering. In J. Jackson (Ed.), The Routledge handbook of language and intercultural communication (pp. 181-194). London, UK: Routledge.

Duff, P. (2012). How to carry out case study research. In A. Mackey \& S. M. Gass (Eds.), Research methods in second language acquisition: A practical guide (pp. 95-116). Oxford, UK: WileyBlackwell.

Duff, P. A., \& Uchida, Y. (1997). The negotiation of teachers' socio-cultural identities and practices in postsecondary EFL classrooms. TESOL Quarterly, 31(3), 451-486.

Frable, D.E.S. (1997). Gender, racial, ethnic, sexual, and class identities. Annual Review of Psychology, 48, 139-162.

Fuertes, J. N., Gottdiener, W. H., Martin, H., Gilbert, T. C., \& Giles, H. (2012). A meta - analysis of the effects of speakers' accents on interpersonal evaluations. European Journal of Social Psychology, 42 (1), 120-133.

Gee, J. P. (2001). Identity as an analytic lens for research in education. Review of Research in Education, 25(1), 99-125.

Giddens, A. (1991). Modernity and self-identity: Self and society in the late modern age. California: Stanford University Press.

Giles, H., \& Johnson, P. (1981). The role of language in ethnic group formation. In J. C. Turner \& H. Giles (Eds.), Intergroup behavior (pp. 199-243). Oxford, UK: Basil Blackwell.

Goffman, E. (1959). Presentation of self in everyday life. Garden City, NY: Double Day Anchor Books.

Goffman, E. (1981). Footing. In E. Goffman (Ed.), Forms of Talk (pp. 124-159). Oxford, UK: Blackwell.

Hall, S. (1996). Introduction: Who needs identity? In S. Hall and P. du Gay (Eds.), Questions of cultural identity (pp. 1-17). London, UK: Sage.

Harré, R. (2001). The discursive turn in social psychology. In D. Schiffrin, D. Tannen, \& H. E. Hamilton (Eds.), The handbook of discourse analysis (pp. 688-706). Oxford, UK: Blackwell Publishers Ltd.

Harré, R., \& Moghaddam, F. (2003). The self and others: Positioning individuals and groups in personal, political, and cultural contexts. Westport, Ireland: Praeger.

Harré, R., \& Slocum, N. (2003). Disputes as complex social events: On the uses of positioning theory. Common Knowledge, 9(1), 100-118.

Harré, R., \& van Langehove, L. (1991). Varieties of positioning. Journal for the Theory of Social Behaviour, 21(4), 393-407.

Harré, R., \& van Langehove, L. (1999). Positioning theory: Moral context of intentional action. Oxford, UK: Blackwell.

Hogg, M. A., \& Abrams, D. (1988). Social identifications: A social psychology of intergroup relations and processes. London, UK: Routledge.

Howard, J. A. (2000). Social psychology of identities. Annual Review of Sociology, 26(1), 367-393.

Huang, I. C. (2014). Contextualizing teacher identity of non-native-English speakers SU.S. secondary ESL classrooms: A Bakhtinian perspective. Linguistics and Education, 25, 119128. 
Huang, I. C. (2018). Power and ownership within the NS/NNS dichotomy. In B. Yazan \& N. Rudolph (Eds.), Criticality, teacher identity, and (in) equity in English language teaching (pp. 41-56). Cham, Switzerland: Springer.

Kayi-Aydar, H. (2015a). Teacher agency, positioning, and English language learners : Voices of pre-service classroom teachers. Teaching and Teacher Education, 45, 94-103. https://doi.org/10.1016/j.tate.2014.09.009

Kayi-Aydar, H. (2015b). Multiple Identities, Negotiations, and Agency Across Time and Space: A Narrative Inquiry of a Foreign Language Teacher Candidate. Critical Inquiry in Language Studies, 12(2), 137-160. doi: 10.1080/15427587.2015.1032076

Lewis, R. (2003). Gendering orientalism: Race, femininity and representation ( $2^{\text {nd }}$ ed.). Routledge

Maloney, J. (2018). Fulbright FLTA CALL Knowledge Development and Enactment: The Role of Context (Doctoral dissertation). Available from ProQuest Dissertations \& Theses Global database. (UMI No. 10812437).

Miles, M. B., \& Huberman, A. M. (1994). Qualitative data analysis: A sourcebook of new methods (2nd ed.). Thousand Oaks, CA: Sage.

Mutlu, S., \& Ortaçtepe, D. (2016). The identity (re)construction of- nonnative English teachers stepping into native Turkish teachers' shoes. Language and Intercultural Communication, 16(4), 552-569. https://doi.org/10.1080/14708477.2016.1194852

Pedersen, E. R., Neighbors, C., Larimer, M. E., \& Lee, C. M. (2011). Measuring sojourner adjustment among American students studying abroad. International Journal of Intercultural Relations, 35(6), 881-889.

Peker, H., Torlak, M., Toprak-Çelen, E., Eren, G., \& Günsan, M. (2020). Language teacher identity construction of foreign language teaching assistants. International Online Journal of Education and Teaching, 7(1), 229-246.

Rosenberg, M. (1979). Conceiving the Self. New York, NY: Basic Books

Ryan, J. (2013). Listening to 'other' intellectual traditions: Learning in transcultural spaces. In J. Ryan (Ed.), Cross-cultural teaching and learning for home and international students (pp. 279-289). Oxon, UK: Routledge.

Sato, T., \& Hodge, S. R. (2013). Japanese students' academic and social experiences at a predominantly white university in the United States. Multicultural Learning and Teaching, 8(1), 93-114.

Slocum-Bradley, N. (2010). The positioning diamond: A trans-disciplinary framework for discourse analysis. Journal for the Theory of Social Behaviour,40(1), 79-107.

Spurling, N. (2006). Exploring adjustment: The social situation of Chinese students in UK higher education. Learning \& Teaching in the Social Sciences, 3(2), 95-117.

Uzum, B. (2012). A microethnographic case study of Fulbright Language Teaching Assistants: Dialogic mediation and conceptual thinking for professional identity development. In G. Gorsuch (Ed.) Working theories for teaching assistant and international teaching assistant development (pp. 388-422). Stillwater, OK: New Forums Press.

Uzum, B. (2017). Uncovering the layers of foreign language teacher socialization: A qualitative case study of Fulbright language teaching assistants. Language Teaching Research, 21(2), 241-257.

van Langehove, L., \& Harré, R. (1999). Introducing positioning theory. In R. Harré \& L. van Langehove (Eds.), Positioning theory: Moral context of intentional action. Oxford, UK: Blackwell.

Wenger, E. (1998). Communities of practice: Learning, meaning, and identity. New York, NY: Cambridge University.

West, C., \& Zimmerman, D. H. (1987). Doing gender. Gender \& society, 1(2), 125-151. 
Widdicombe, S., \& Wooffitt, R. (1995). The language of youth subcultures: Social identity in action. Hemel Hempstead, UK: Harvester Wheatsheaf.

Wodak, R., De Cillia, R., Reisigl, M., \& Liebhart, K. (2009). Discursive construction of national identity ( $2^{\text {nd }}$ Ed.). Edinburgh: Edinburgh University Press.

\section{Appendix A. A sample set of interview questions (semi-structured, in Turkish)}

\section{Öğretmen rolüne dair sorular}

FLTA programı dahilinde gitmiş olduğunuz kurumun/bölümün eğitim politikasından bahseder misiniz? Kurumun eğitim politikası ile kişisel eğitim anlayışınızın çatıştığı durumlar yaşadınız mı? Örneğin, kurumun sizden beklentisi olan öğretim metotları, materyaller, öğrencileriniz ile aranızdaki ilişkinin boyutu vb. [Bu durumu nasıl yönettiniz?]

Kendi ülkenizde İngilizce yabancı dil öğretmeni iken, ev sahibi kurumuzda ana dil öğretmeni olmak nasıl bir duyguydu? Bu durumu nasıl değerlendirirsiniz?

\section{Öğrenci rolüne dair sorular}

FLTA programı kapsamında öğrencilik yaşantınızdan bahsedelim. Türkiye'deki öğrencilik yaşantınızı ve Amerika Birleşik Devletleri’ndeki öğrencilik yaşantınızı karşılaştırmalı bir şekilde göz önünde bulunduralım. Uyum sağlamakta zorlandığınız herhangi bir durumla karşılaştınız mı?

\section{Kültür elçisi rolüne dair sorular}

FLTA programı kapsamında sosyal ve kültürel yaşantılarınızdan bahsedelim. FLTA sürecinizde kültür aktarımı rolü üstlendiniz, bu kapsamda ne gibi etkinlikler düzenlediniz?

FLTA olarak gittiğiniz bölgedeki sosyal yaşantınızdan bahseder misiniz?

Bu süreçte farklı kültürlerden insanlarla iletişiminizden bahseder misiniz?

\section{Appendix B. A sample set of interview questions (semi-structured, in English)}

\section{Questions about the teaching assistant role}

Could you tell us about the education policy of the institution/department you attended within the FLTA program? Have you experienced situations where the education policy of the institution and your understanding of personal education conflict? For example, teaching methods that the institution expects from you, materials, the extent of your relationship with your students, etc.

[How did you manage this situation?]

How did it feel to be a first language teacher at the host institution when you were an English as a foreign language teacher in your home country? How would you evaluate this situation?

Questions about the student role 
Let us talk about your experiences as a student during the FLTA program. Let us consider your student life in Turkey and your student life in the US in a comparative way. Have you experienced any situations that you struggled to adapt to? Any situations that you had difficulties adapting to?

\section{Questions about the cultural ambassador role}

Let us talk about your social and cultural experiences during the FLTA program. You took on the role of culture transmission in your FLTA process. What kind of activities did you organize in this context?

Could you tell us about your social life in the region you have been as an FLTA?

Could you tell us about your communication with people from different cultures in this process?

\section{Copyrights}

Copyright for this article is retained by the author(s), with first publication rights granted to the Journal. This is an open-access article distributed under the terms and conditions of the Creative Commons Attribution license (CC BY-NC-ND) (http://creativecommons.org/licenses/by-nc-nd/4.0/). 